\title{
Review
}

\section{At the Limits of the Political: Affect, Life, Things}

\author{
Inna Viriasova \\ Rowman \& Littlefield International, London, 2018, vii+03 pp., \\ ISBN 978-1-78660-456-9.
}

Contemporary Political Theory (2020) 19, S48-S50. https://doi.org/10.1057/s41296018-0251-2; published online 6 August 2018

Inna Viriasova's At the Limits of the Political: Affect, Life, Things explores different ways of thinking about 'the unpolitical'. The book opens with a clear and insightful definition of this category: the unpolitical is 'the radical or absolute outside of politics that remains indifferent to the problems of political cobelonging' (p. 1). The author's aim is two-fold. First, she shows how the political has become a totalizing category in contemporary continental political philosophy. Secondly, she argues for the need to think about a space outside of politics. The clarity of style and lack of jargon characterize the entire text, which addresses not only important contributions in continental philosophy, but also non-western traditions such as Buddhism.

The book is divided into two parts. In the first, Viriasova convincingly argues that one of the hegemonic tendencies in continental political philosophy ever since the second half of the twentieth century has been the progressive affirmation of the category of 'the political' and the consequent growing impossibility to think about what lies outside of politics. Such a process of erasure has involved 'the critique of transcendence, the disappearance of the state of nature, and the politicization of life and ontology' (p. 7). The result of this gradual loss of the outside has led to the conclusion that everything is political, meaning that being-qua-being is political. In order to outline this philosophical perspective, the author takes into consideration the works of three of the main architects of the category of the political - Carl Schmitt, Jean-Luc Nancy, and Michel Foucault - dedicating a chapter to each of them. The main areas in which the action of politicization is visible are those of nature, life, and ontology. In the works of each of the three philosophers, these themes are elaborated to a greater or lesser degree. Viriasova is careful to underline that these authors are part of a larger archipelago of thinkers belonging to the poststructuralist and post-foundational traditions. Her analysis of Schmitt, Nancy, and Foucault clearly shows how the works of these thinkers are not a one-dimensional structure reducible to a philosophy of the political. For instance, in her reading of

(c) 2018 Springer Nature Limited. 1470-8914 Contemporary Political Theory Vol. 19, S1, S48-S50 
Foucault, she shows how the French philosopher proposes a notion of life as means to resistance to biopolitics. This Foucauldian notion of life can be interpreted as a starting point for an unpolitical philosophy of life. Viriasova seems to suggest that readings subverting the relationship between ontology and politics as established by the philosophy of the political can be developed not only for Foucault, but also for Schmitt and Nancy (see Prozorov, 2018).

The first part of the book continues with other two chapters, dedicated respectively to the category of the 'impolitical' in Massimo Cacciari and Roberto Esposito, and that of form-of-life in Giorgio Agamben. According to Viriasova, these authors let emerge the limits of modern politics showing a path towards the unpolitical. The second part of the book addresses the question of the unpolitical, which should not be confused with a relative outside: the unpolitical is a radical and absolute outside of politics. The author maps this category as thanks to the analysis of Quentin Meillassoux's speculative realism, Michel Henry's radical phenomenology of life and Buddhist philosophy of compassion, dedicating a chapter to each of these topics. Viriasova develops with clarity and acumen her position which eventually leads to the notion of 'impersonal justice' (p. 167). This notion borrows ideas from the three previous chapters, but finds its grounding principle in the Buddhist idea of compassion, which is 'a universal affect that can and must be practically cultivated in order to develop into a transformative action that appears in the world. It also uproots anthropocentric conceptions of sociality and lays a ground for a posthumanist conception of community, embracing an interspecies model' (p. 13).

I think the question which Viriasova addresses is very important and her critique of the totalizing tendency of the political is clear and convincing. The authors and philosophical traditions she chooses in order to define the unpolitical certainly deserve attention and the way Viriasova combines them is original and thoughtful. However, her definition of the unpolitical is marked by an anti-naturalist and antiscientific tendency, which, I believe, endangers her project. For example, when she argues for a redefinition of humanism, she does not acknowledge in any way the relevance of natural sciences in challenging some of the basic assumptions of traditional humanism, such as dualism and anthropocentrism. Even if she tries to leave science at the door, it inevitably makes its way back in when Viriasova employs scientific terms - such as 'species' - to define her post-humanist approach. The author's anti-scientific attitude emerges even more strongly when she addresses the notions of life and biopolitics. She writes that the 'biopolitical government of life is grounded in the objectification of life' (p. 177). Hence, resisting biopolitics means to affirm that 'biology knows nothing of life' (p. 140) and to find an authentic 'unpolitical form-of-life' (p. 178) in a space that Agamben would probably call 'great ignorance'. The complete overlap between science and biopolitical techniques is a theoretical move typical of the philosophical tradition she wants to challenge: it is political ontology which argues that every notion of biological life is an 'epistemological indicator' created by the discourse/power regimes.

(c) 2018 Springer Nature Limited. 1470-8914 Contemporary Political Theory Vol. 19, S1, S48-S50 S49 
On the contrary, it could - and probably should - be noticed that it is science that allows us to deprive life itself of any intrinsic political design, therefore making biological life essentially unpolitical. Generalizations are always dangerous, but it is possible to maintain that a consistent part of biological sciences maintains that there is no design in the processes characterizing life itself; if there is no design to realize and/ or restore, there is no ontological ground for a normative biopolitics. This is not to say that all science is good science (see Tarizzo, 2018) or that science is the only way to define an unpolitical notion of life, but rather that a critical approach to biological sciences should be among the elements of an unpolitical notion of life.

Finally, a quick remark on Meillassoux. The role that this philosopher ends up playing within the unpolitical horizon traced by Viriasova is ambivalent. Meillassoux is one of the main critics of the post-Kantian anti-realism, but, as Brassier maintains, he also 'conducts his case against correlationism in a logical rather than empirical register ... this leads him to reiterate the Cartesian dualism of thought and extension' (Brassier, 2007, p. 58). When Meillassoux directly addresses the mind-body problem on the basis of his speculative position, the result 'amounts to an anti-scientific sophistical sleight-of-hand that places Meillassoux in undeniable proximity to the same Christian creationists he mocks in After Finitude' (Johnston, 2011, p. 97).

If Viriasova's aim is to think about the unpolitical and the post-human, it seems that a debate with naturalism and life sciences is needed. It might be the case that Buddhist philosophy is able to overcome all the problematic issues of traditional humanism such as dualism and anthropocentrism - without the help of science, but, if this is the case, a more developed argument is needed. I personally think that a dialog with biological sciences is in any case inevitable. Whatever the answer to this question, it is also worth considering that a book cannot solve all those problems.

\section{References}

Brassier, R. (2007). Nihil Unbound Enlightenment and Extinction. New York: Palgrave Macmillan. Johnston, A. (2011). 'Hume's Revenge: À Dieu, Meillassoux'. In L. Bryant, N. Srnicek, \& G. Harman (Eds.), The speculative turn: continental materialism and realism. Melbourne: Re.Press.

Prozorov, S. (2018). A thousand healths: Jean-Luc Nancy and the possibility of democratic biopolitics. Philosophy and Social Criticism, 44(5), 1-19.

Tarizzo, D. (2018). Life. A Modern Invention. Minneapolis: Minnesota University Press.

Marco Piasentier University of Jyväskylä, 40014 Jyväskylä, Finland marco.piasentier@gmail.com 